\title{
Selected Sri Lankan food plants and other herbs as potential sources of inulin-type fructans
}

\author{
D.C. Mudannayake ${ }^{1}$ K.M.S. Wimalasiri ${ }^{2 *}$ K.F.S.T. Silva ${ }^{3}$ and S. Ajlouni ${ }^{4}$ \\ ${ }^{1}$ Department of Animal Science, Faculty of Animal Science and Export Agriculture, Uva Wellassa University, Badulla. \\ ${ }^{2}$ Department of Food Science and Technology, Faculty of Agriculture, University of Peradeniya, Peradeniya. \\ ${ }^{3}$ Department of Animal Science, Faculty of Agriculture, University of Peradeniya, Peradeniya. \\ ${ }^{4}$ Bioscience Section, Faculty of Veterinary and Agricultural Sciences, The University of Melbourne, Victoria 3010, Australia.
}

\begin{abstract}
The objective of this study was to determine the inulin-type fructan content in 20 selected food plants and other herbs commonly found in Sri Lanka. The inulin content of the selected plants were determined qualitatively and quantitatively using thin layer chromatography (TLC) and enzymatic spectrophotometric (ES) methods, respectively. The ES results showed that the inulin-type fructan contents based on fresh weight was highest in Allium sativum (18.62\% $\pm 1.55)$, followed by Asparagus falcatus (17.74 \% \pm 2.92$)$, Asparagus racemosus (11.8 3\% \pm 0.87$)$, Allium cepa $(8.60 \%$ $\pm 0.88)$, Allium ampeloprasum $(6.20 \% \pm 0.23)$, Taraxacum javanicum $(5.77 \% \pm 1.53)$ and Vernonia cinerea $(4.55 \%$ \pm 0.93 ), respectively. Taraxacum javanicum and Vernonia cinerea plant extracts developed distinct blue black spots with the detection reagent on TLC plates similar to chicory inulin standard. However, Allium ampeloprasum, Allium cepa, Allium sativum, Asparagus falcatus and Asparagus racemosus developed thicker blue black streaks on TLC plates due to their higher inulin concentration, which confirmed the ES results. Aloe vera, Alpinia calcarata, Amophophallus campanulatus, Beta vulgaris, Canna indica, Diascorea alata and Sonchus oleraceus contained low levels $(1 \leq 0.5 \mathrm{~g} / 100 \mathrm{~g}$ FW) of inulin while Caryota urens, Ipomoea batatas, Lasia spinosa and Maranta arundinacea contained very low levels or no $(<0.4 \mathrm{~g} / 100 \mathrm{~g} \mathrm{FW})$ inulin.
\end{abstract}

Keywords: Allium sativum, Asparagus falcatus, Asparagus racemosus, chicory, enzymatic spectrophotometric assay, inulin-type fructans, thin layer chromatography.

\section{INTRODUCTION}

Inulin-type fructans are non digestible, polydisperse carbohydrate materials made up of fructose units, connected mostly or exclusively of $\beta(2 \rightarrow 1)$ fructosyl fructose linkages with an optional terminating glucose molecule. They are considered linear or branched fructose polymers with a degree of polymerization of 2-60 (Roberfroid, 2005; 2007b).

Inulin-type fructans have gained much interest in the food industry as 'functional food ingredients' because they have the ability to selectively stimulate the activities and growth of beneficial microflora (specifically Bifidobacteria and some Lactobacillus species) in the human colon, maintain a healthy balance of microflora in the colon and promote the integrity of colon epithelium (Roberfroid, 2005). They are well documented and proven as 'prebiotics', and have been claimed to improve intestine immune functions, reduce blood cholesterol levels, improve absorption of $\mathrm{Ca}$ and $\mathrm{Mg}$, reduce the risk of irritable bowel diseases (IBD) and more importantly reduce the risk of colon cancer (Sako \& Tanaka, 2002).

Inulin-type fructans naturally occur as storage carbohydrates in some families of plants representing approximately 30,000 species (Niness, 1999; Singh \& Singh, 2010). Plants in the families Asteraceae, Asparagaceae, Amaryllidaceae and Campanulaceae are well known to store inulin-type fructans. Several studies have shown the distribution of inulin-type fructans in a variety of food plants (Loo et al., 1995; Campbell et al., 1997; Judprasong et al., 2011; Moongngarm et al., 2011). There are many food plants and herbs in Sri Lanka, which may contain high levels of inulin-type fructans. 
Currently widely marketed commercial inulin is extracted from two plants of the family Asteraceae; Cichorium intybus (chicory) and Helianthas tuberosus (Jerusalem artichoke), which are not found in Sri Lanka. Commercial inulin extracted from chicory is imported to Sri Lanka from European countries at a high cost for food processing applications. Therefore it is important to search for locally available sources of inulin-type fructans for commercial inulin extraction. Hence this study was aimed at screening selected food plants and other herbs in Sri Lanka for inulin-type fructans to identify potential plant sources for inulin extraction.

\section{METHODS AND MATERIALS}

\section{Selection of plants}

The selection of plants was based on previous studies on inulin-type fructan contents in food plants (Loo et al., 1995; Campbell et al., 1997; Judprasong et al., 2011) and medicinal plants used in Ayurveda, the Sri Lankan traditional medicine and the alternative medicine for treating digestive tract related disorders (Jayasinghe et al., 1979; 1985; Jayaweera, 1980; 1981a; b; 1982).

Table 1: Scientific name, common name, family and analyzed part of the plants

\begin{tabular}{|c|c|c|c|}
\hline Scientific Name & $\begin{array}{l}\text { Common name } \\
\text { (English/Sinhala) }\end{array}$ & Family & Plant part analyzed \\
\hline \multicolumn{4}{|l|}{ Traditional yams and starchy foods } \\
\hline Amophophallus campanulatus & Elephant foot yam/ Kidaran & Araceae & Tuber \\
\hline Canna indica L. (green) & Queensland arrowroot/ Buthsarana sudu & Canaceae & Tuber \\
\hline Canna indica L. (red) & Queensland arrowroot/ Buthsarana rathu & Canaceae & Tuber \\
\hline Caryota urens $\mathrm{L}$. & Kithul palm & Arecaceae & Flour from heart of stem \\
\hline Diascorea alata $\mathrm{L}$. & Purple yam/ Raja ala & Diascoreaceae & Tuber \\
\hline Ipomoea batatas (L.) Lam. (red) & Sweet potato/ Rathu bathala & Convolvulaceae & Tuber \\
\hline Ipomoea batatas (L.) Lam. (yellow) & Sweet potato/ Kaha bathala & Convolvulaceae & Tuber \\
\hline Maranta arundinacea $\mathrm{L}$. & Arrowroot/ Hullankeeriya & Marantaceae & Tuber \\
\hline \multicolumn{4}{|l|}{ Spices } \\
\hline Allium cepa $\mathrm{L}$. & Shallot/ Rathulunu & Amaryllidaceae & Bulb \\
\hline Allium sativum $\mathrm{L}$. & Garlic/ Sudu lunu & Amaryllidaceae & Bulb \\
\hline \multicolumn{4}{|l|}{ Vegetables } \\
\hline Allium ampeloprasum $\mathrm{L}$. & Leeks & Amaryllidaceae & Leaf base \\
\hline Beta vulgaris L. & Beet root & Chenopodiaceae & Tap root \\
\hline Lasia spinosa (L.) Thw. & Kohila & Araceae & Rhizome \\
\hline \multicolumn{4}{|l|}{ Herbs } \\
\hline Aloe vera (L.) Burm.f. & Aloe/Komarika & Aloaceae & Leaf gel \\
\hline Alpinia calcarata Roscoe & Heen araththa & Zingiberaceae & Rhizome \\
\hline Asparagus falcatus $\mathrm{L}$. & Hathawariya & Asparagaceae & Root \\
\hline Asparagus racemosus Willd. & Hathawariya wild & Asparagaceae & Root \\
\hline Vernonia cinerea $(\mathrm{L}$.$) Less$ & Ash coloured fleabane/ Monarakudumbiya & Asteraceae & Root \\
\hline \multicolumn{4}{|l|}{ Wild herbs } \\
\hline Taraxacum javanicum v. Soest & Dandelion & Asteraceae & Tap root \\
\hline Sonchus oleraceus L. & Sow thistle/Galpothu kola & Asteraceae & Tap root \\
\hline
\end{tabular}

(Source: Jayaweera, 1980; 1981 a; b; 1982; Senaratna, 2001)

Accordingly, twenty plants available in Sri Lanka were selected. They included eight traditionally used yams and starchy food plants, two spices, three vegetables and seven herbs of which two were wild herbs. These are used as food in Sri Lanka and/or other Asian/European countries. The scientific names, common names and the plant parts analyzed have been listed in Table 1 . 


\section{Collection of plant material}

Amophophallus campanulaus, Canna indica, Diascorea alata, Ipomoea batatas and Maranta arundinacea, were collected from the fields of the Horticulture Crop Research and Development Institute, Gannoruwa. Alpinia calcarata and Asparagus racemosus were collected from the Research Medicinal Plants Garden, Pattipola, while Sonchus oleraceus and Taraxacum javanicum were collected from the road sides of Pattipola. Aloe vera and Asparagus falcatus were collected from home gardens in Peradeniya, while Vernonia cinerea was collected from the road sides of Gannoruwa, Sri Lanka. Allium ampeloprasum, Allium cepa, Allium sativum, Beta vulgaris, Caryota urens (pith flour), and Lasia spinosa were purchased from the local market in Peradeniya. The plants used in the study were identified and authenticated by the National Herbarium, Royal Botanical Gardens, Peradeniya, Sri Lanka. All the plant parts as given in Table 1 (except Caryota urens flour) were thoroughly washed with tap water to remove soil and other unwanted material and dried with paper towels.

Qualitative determination of fructan using thin layer chromatography (TLC) analysis

\section{Extraction of fructan for TLC analysis}

The edible portions of the cleaned and peeled parts of the plants were weighed $(6 \mathrm{~g})$ and cut into small pieces of $2 \mathrm{~mm}$, and immediately introduced into conical flasks filled with $50 \mathrm{~mL}$ of warm $\left(70^{\circ} \mathrm{C}\right)$ distilled water. The conical flasks were covered with parafilm and placed on a shaking water bath at a constant temperature $\left(85 \pm 2{ }^{\circ} \mathrm{C}\right)$ for $15 \mathrm{~min}$ to extract the fructans and sugars (McCleary et al., 2000).

\section{Preparation of standards and detection reagent}

Glucose, fructose and sucrose standards were prepared at a concentration of $3 \mathrm{mg} / \mathrm{mL}$. Potato starch (Thomas Baker Chemicals, India), chicory inulin and chicory fructooligo saccharide (FOS) standards (Beno Orafti, Belgium) were prepared at a concentration of $5 \mathrm{mg} / \mathrm{mL}$. The detection reagent was prepared by dissolving diphenylamine $(2 \mathrm{~g})$ and aniline $(2 \mathrm{~mL})$ in acetone $(80 \mathrm{~mL})$, carefully adding $15 \mathrm{~mL}$ of phosphoric acid and diluting to $100 \mathrm{~mL}$ with acetone. $100 \mathrm{~mL}$ of the detection reagent was used as dipping solution (Reiffova \& Nemcova, 2006).

\section{Qualitative thin layer chromatography (TLC) analysis}

Thin layer chromatography analyses of the plant extracts were carried out as described by Reiffova and Nemcova
(2006) with slight modifications. Prior to TLC analysis, chromatographic silica gel $60 \mathrm{~F}_{254}(200 \times 200 \mathrm{~mm})$ pre-coated aluminum sheets (Merck KGaA, Germany) were pre-treated with $0.02 \mathrm{M}$ sodium acetate, followed by drying in an oven at $50{ }^{\circ} \mathrm{C}$ for $5 \mathrm{~min}$. Equal volumes (approximately $0.5 \mu \mathrm{L}$ ) of glucose, fructose, sucrose, potato starch, inulin, FOS standards and plant extracts were spotted manually on TLC plates using capillary tubes. The TLC plates were developed two times in butanol:ethanol:water $[5: 3: 2(\mathrm{v} / \mathrm{v} / \mathrm{v})]$ solvent system at room temperature with air drying in between the two developments. After development, the plates were dried for $10 \mathrm{~min}$ in a stream of warm air. The plates were then dipped in detection reagent for $5 \mathrm{~s}$ and allowed to dry at room temperature for $10 \mathrm{~min}$. Blue-black spots were visualized by heating the plates in an oven at $120{ }^{\circ} \mathrm{C}$ for $20 \mathrm{~min}$.

Quantitative determination of fructan using enzymatic spectrophotometric method

\section{Enzymatic spectrophotometric method}

The fructan contents in the plant extracts were determined using the enzymatic spectrophotometric method (AOAC method 999.03) using Megazme fructan assay kit (Megazyme, Ireland), which contained sucrase, fructanase, fructan control, sucrose control and D- fructose standard.

\section{Extraction of fructan for enzymatic spectrophotometric method}

Cleaned (peeled) plant parts were grated using a cheese grater (thickness $<1 \mathrm{~mm}$ ), accurately weighed $(1.0 \mathrm{~g}$ ) and immediately put into conical flasks filled with $80 \mathrm{~mL}$ of hot distilled water $\left(\sim 70{ }^{\circ} \mathrm{C}\right)$. The fructans and sugars were extracted as explained earlier in TLC analysis. The extract was allowed to cool to room temperature and quantitatively transferred into a $100 \mathrm{~mL}$ volumetric flask. The volume was adjusted to $100 \mathrm{~mL}$ with distilled water, thoroughly mixed and filtered through a Whatman No. 1 filter paper. The filtered solution was used for analysis immediately. Fructan control powder (25.5\% fructan) (Megazyme, Ireland) was extracted $(100 \mathrm{mg}$ in $50 \mathrm{~mL}$ of distilled water) using the same procedure along with the samples (Megazyme, 2012).

\section{Preparation of enzymes and reagents}

Sucrase/ amylase and fructanase enzyme solutions were prepared as described by McCleary et al. (2000) and stored in a freezer at $-20{ }^{\circ} \mathrm{C}$ until use. D-fructose standard solution and para-hydroxybenzoic acid hydrazide (PAHBAH) reducing sugar assay reagent 
were prepared as described in McCleary et al. (2000), immediately before use.

\section{Removal of sucrose, starch and reducing sugars}

Aliquots of the extracted sample $(0.2 \mathrm{~mL})$ was mixed with diluted sucrase/ amylase enzyme solution $(0.2 \mathrm{~mL})$ in a glass test tube and incubated at $40{ }^{\circ} \mathrm{C}$ for $30 \mathrm{~min}$. Then $0.2 \mathrm{~mL}$ of freshly prepared alkaline borohydrate solution $(10 \mathrm{mg} / \mathrm{mL}$ sodium borohydride in $50 \mathrm{mM}$ sodium hydroxide) (Sigma-aldrich, USA) was added to the sample, vigorously stirred and incubated at $40{ }^{\circ} \mathrm{C}$ for $30 \mathrm{~min}$. The samples were then mixed with $0.5 \mathrm{~mL}$ of $0.2 \mathrm{M}$ acetic acid followed by vigorous stirring on a vortex mixer. This extract solution was used for hydrolysis and measurement of fructans (McCleary et al., 2000).

\section{Hydrolysis of fructans}

Aliquots $(0.2 \mathrm{~mL})$ of the above extract solution were dispensed into the base of three glass test tubes $(16 \times 100$ $\mathrm{mm})$. Fructanase enzyme solution $(0.1 \mathrm{~mL})$ was added to two test tubes (samples) while $0.1 \mathrm{M}$ sodium acetate buffer $(0.1 \mathrm{~mL})$ was added to the third test tube (sample blank). All test tubes were sealed with Parafilm ${ }^{\circledR}$ and incubated at $40{ }^{\circ} \mathrm{C}$ for $60 \mathrm{~min}$ for the complete hydrolysis of fructan into D-glucose and D-fructose (McCleary et al., 2000).

\section{Measurement of fructans}

PAHBAH working reagent $(5.0 \mathrm{~mL})$ was added to all test tubes (samples, sample blanks, reagent blanks, fructan control, D- fructose standard) and immediately immersed in a boiling water bath for exactly 6 min (McCleary et al., 2000). All the tubes were then placed in cold water $\left(18-20^{\circ} \mathrm{C}\right)$ for $5-6 \mathrm{~min}$ and the absorbance measured within $10-15$ min against reagent blank at $410 \mathrm{~nm}$ using UV-visible spectrophotometer (UV-1601, Shimadzu Co., Japan). Three independent fructan extractions and measurements were performed for each plant species used in the study. In order to validate the method of analysis, standard inulin-type fructan samples $(25.5 \%$ inulin) were analysed in parallel to each independent measurement.

Determination of some other constituents of plant samples

Proximate moisture, ash, crude fat, crude protein and crude fiber contents

Moisture, ash, fat, protein and fiber content of the plant samples were determined according to the methods described in AOAC (2005).

\section{Total water soluble sugars}

Total water soluble sugars of the plant samples were determined using the phenol-sulfuric method using glucose as the standard (Dubois et al., 1956). Approximately $1.0 \mathrm{~g}$ of pre-prepared plant sample was weighed and extracted in $100 \mathrm{~mL}$ of hot water as described under TLC analysis, and $1.0 \mathrm{~mL}$ aliquot of each plant extract was diluted in $250 \mathrm{~mL}$ volumetric flasks using distilled water. An aliquot $(1.0 \mathrm{~mL})$ of the diluted solution was transferred to a glass test tube (16 $\times 100 \mathrm{~mm})$ and mixed with an equal volume $(1.0 \mathrm{~mL})$ of $5 \%(\mathrm{v} / \mathrm{v})$ phenol. Concentrated sulfuric acid $(5.0 \mathrm{~mL})$ was added to each test tube, mixed well and allowed to incubate at $30{ }^{\circ} \mathrm{C}$ in a water bath. The absorbance was measured at $490 \mathrm{~nm}$ using UV-visible spectrophotometer (UV-1601, Shimadzu Co., Japan).

\section{RESULTS AND DISCUSSION}

\section{Qualitative TLC analysis}

The developed TLC plate showed distinct blue-black spots or spot patterns representing glucose, fructose, sucrose, inulin and FOS while potato starch did not show any spots (Figure 1). The TLC results (Figure 1) confirmed that Allium ampeloprasum (spot number 26), Allium cepa (18), Allium sativum (17), Asparagus falcatus (13), Asparagus racemosus (28), Taraxacum javanicum (25) and Vernonia cinerea (19) contain inulin.

Taraxacum javanicum (25) and Vernonia cinerea (19) plant extracts showed distinct spot patterns similar to chicory inulin standard, while Allium ampeloprasum (26), Allium cepa (18), Allium sativum (17), Asparagus falcatus (13) and Asparagus racemosus (28) showed blueblack streaks instead of spots on TLC plate at the same plant extract concentration. Streaks are developed instead of spots on the TLC plates due to higher concentration of the sample (Hahn-Deinstrop, 2007). Therefore it appears that the inulin content in Allium ampeloprasum (26), Allium cepa (18), Allium sativum (17), Asparagus falcatus (13) and Asparagus racemosus (28) is higher than that of Taraxacum javanicum (25) and Vernonia cinerea (19). When TLC analysis was carried out after diluting high and medium fructan containing plant extracts (Allium ampeloprasum, Allium cepa, Allium sativum, Asparagus falcatus and Asparagus racemosus) 3 times with distilled water $(\mathrm{v} / \mathrm{v})$, distinct spot patterns similar to chicory inulin standard were observed (Figure 2). This result was confirmed by the subsequent Megazyme fructan assay results. 


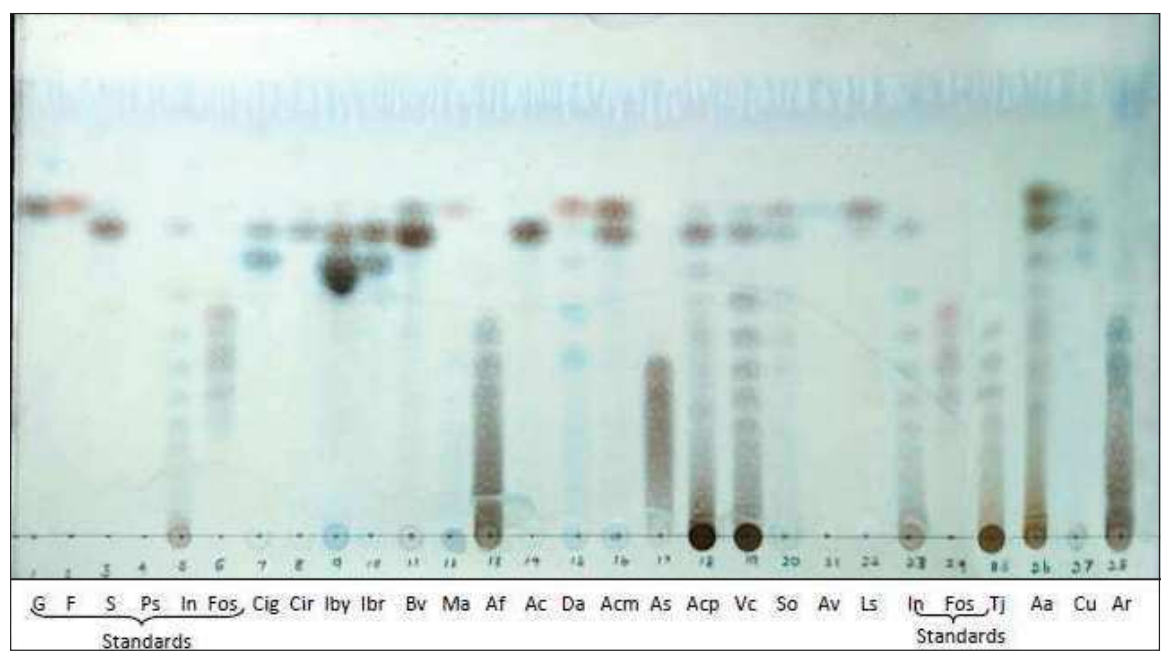

Figure 1: Thin layer chromatogram of inulin-type fructans in 20 plants

1- G (glucose); 2- F (fructose); 3- S (sucrose); 4- Ps (potato starch); 5- In (chicory inulin, Beno orafti®); 6- Fos (chicory fructo-oligosaccharide, Beno orafti®); 7- Cig [Canna indica (var. green)]; 8- Cir [Canna indica (var. red)]; 9- Iby [Ipomoea batatas (var. yellow)]; 10Ibr [Ipomoea batatas (var. red)]; 11- Bv (Beta vulgaris); 12- Ma (Maranta arundinacea); 13- Af (Asparagus falcatus); 14- Ac (Alpinia calcarata); 15- Da (Diascorea alata); 16Acm (Amophophallus campanulatus); 17- As (Allium sativum); 18- Acp (Allium cepa); 19Vc (Vernonia cinerea); 20- So (Sonchus oleraceus); 21- Av (Aloe vera); 22- Ls (Lassia spinosa); 23- In (Chicory inulin, Beno orafti ${ }^{\circ}$ ); 24- Fos (Chicory fructo-oligosaccharide, Beno orafti $($ ); 25- Tj (Taraxacum javanicum); 26- Aa (Allium ampeloprasum) Leeks; 27$\mathrm{Cu}$ (Caryota urens); 28- Ar (Asparagus racemosus)

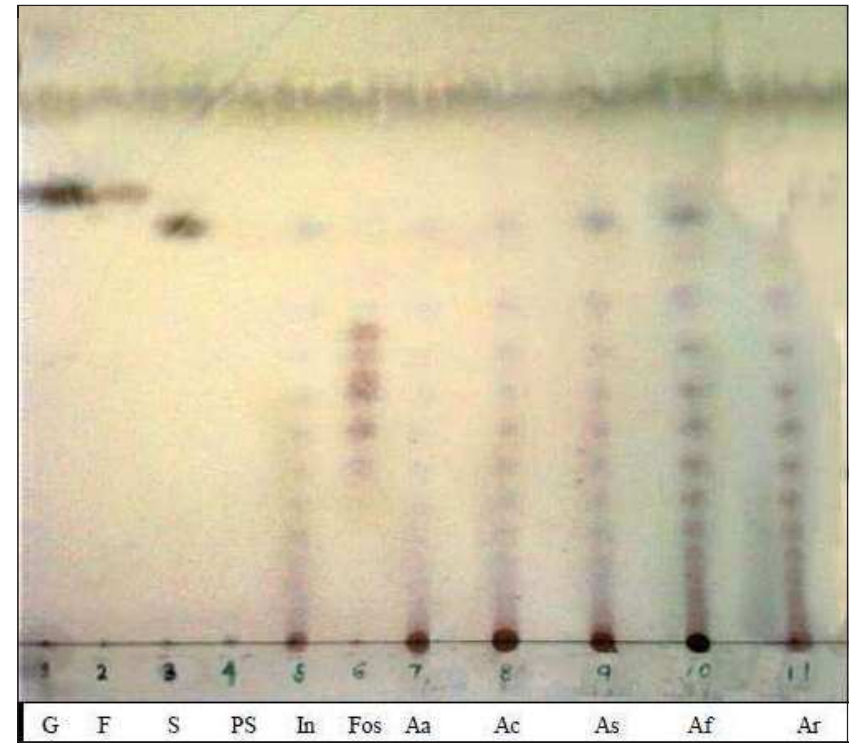

Figure 2: Thin layer chromatogram of inulin-type fructans in 3 times diluted plant extracts 1- G (Glucose); 2- F (Fructose); 3- S (Sucrose); 4- Ps (Potato starch); 5- In (Chiocory inulin, Beno orafti $\left.{ }^{\circledR}\right) ; 6$ - Fos (Chicory fructo-oligosaccharide, Beno orafti $\left.{ }^{\circledR}\right) ; 7$ - Aa (Allium ampeloprasum); 8- Ac (Allium cepa); 9- As (Allium sativum); 10- Af (Asparagus falcatus); 11- Ar (Asparagus racemosus) 


\section{Fructan content in analyzed plants}

The fructan content of the twenty selected plants are presented in Table 2. Among the twenty plants analyzed, Allium sativum (garlic) showed the highest fructan content $(18.62 \pm 1.55 \mathrm{~g} / 100 \mathrm{~g}$ FW). The second and third highest fructan contents were found in Asparagus falcatus (17.74 $\pm 1.29 \mathrm{~g} / 100 \mathrm{~g}$ FW) and Asparagus racemosus (11.83 $\pm 0.87 \mathrm{~g} / 100 \mathrm{~g}$ FW). A medium level of fructan was found in Allium cepa (shallot) and Allium ampeloprasum (leeks), $8.60 \pm 0.88$ g /100 g FW and $6.20 \pm 0.23 \mathrm{~g} / 100 \mathrm{~g} \mathrm{FW}$, respectively. Taraxacum javanicum and Vernonia cinerea contained medium to low levels of inulin-type fructan, $5.77 \pm 1.53$ and $4.55 \pm$ $0.93 \mathrm{~g} / 100 \mathrm{~g}$ FW respectively. Other than that, Sonchus oleraceus, Canna indica (red), Alpinia calcarata, Diascorea alata, Amophophallus campanulatus, Aloe vera and Beta vulgaris contained $1 \geq 0.5 \mathrm{~g} / 100 \mathrm{~g} \mathrm{FW}$ fructan contents, while Maranta arundinacea, Canna indica (green), Lasia spinosa, Ipomoea batatas (red), Ipomoea batatas (yellow) and Caryota urens were found as very low sources of fructan $(<0.4 \mathrm{~g} / 100 \mathrm{~g} \mathrm{FW})$.

The Megazyme fructan assay results were in high level of agreement with the results of TLC analysis (Figure 1) in which Asparagus falcatus (13), Allium sativum (17) and Asparagus racemosus (28) showed thick blue-black streaks on the TLC plates due to high fructan concentrations in the sample. Allium cepa (18) and Allium ampeloprasum (26) developed rather thin blue-black streaks on TLC plates, while Vernonia ceneria (19) and Taraxacum javanicum (25) (medium to low fructan sources) showed distinct spot patterns similar to chicory inulin standard (Figure 1).
Table 2: Inulin-type fructan contents in analyzed plants

\begin{tabular}{lc}
\hline Scientific name & $\begin{array}{c}\text { Inulin-type fructan } \\
\text { content (g/100 g FW)* }\end{array}$ \\
\hline Amophophallus campanulatus & $0.87 \pm 0.06$ \\
Canna indica L.(green) & $0.10 \pm 0.01$ \\
Canna indica L. (red) & $0.67 \pm 0.01$ \\
Caryota urens L. & $0.06 \pm 0.01$ \\
Diascorea alata L. & $0.57 \pm 0.07$ \\
Ipomoea batatas (L.) Lam. (red) & $0.10 \pm 0.01$ \\
Ipomoea batatas (L.) Lam. (yellow) & $0.24 \pm 0.07$ \\
Maranta arundinacea L. & $0.04 \pm 0.01$ \\
& \\
Allium cepa L. & $8.60 \pm 0.88$ \\
Allium sativum L. & $18.62 \pm 1.55$ \\
Allium ampeloprasum L. & $6.20 \pm 0.23$ \\
Beta vulgaris L. & $0.60 \pm 0.04$ \\
Lasia spinosa (L.) Thw. & $0.36 \pm 0.04$ \\
Aloe vera (L.) Burm.f. & $0.51 \pm 0.02$ \\
Alpinia calcarata Roscoe. & $0.87 \pm 0.13$ \\
Asparagus falcatus L. & $17.74 \pm 1.29$ \\
Asparagus racemosus Willd. & $11.83 \pm 0.87$ \\
Vernonia cinerea (L.) Less & $4.55 \pm 0.93$ \\
Taraxacum javanicum v. Soest & $5.77 \pm 1.53$ \\
Sonchus oleraceus L. & $0.75 \pm 0.10$ \\
\hline
\end{tabular}

* Each value for fructan were derived from three independent, duplicated measurements

A comparison of data obtained from the present study with those in previous literature is presented in Table 4. Accordingly, the level of inulin in Allium sativum (garlic) from this study $(18.62 \pm 1.55 \mathrm{~g} / 100 \mathrm{~g} \mathrm{FW})$ is slightly

Table 3: Comparison of inulin-type fructan contents in the present study with data from literature

\begin{tabular}{|c|c|c|c|c|c|c|}
\hline \multirow[t]{2}{*}{ Scientific name } & \multicolumn{6}{|c|}{ Inulin-type fructan content ( $\mathrm{g} / 100 \mathrm{~g}$ fresh basis) } \\
\hline & $\begin{array}{l}\text { Loo et al., } \\
1995^{1} \\
\text { (Inulin) }\end{array}$ & $\begin{array}{c}\text { Campbell et al., } \\
1997^{2} \\
\text { (FOS) }\end{array}$ & $\begin{array}{c}\text { Gupta \& Kaur, } \\
1997^{3} \\
\text { (Inulin) }\end{array}$ & $\begin{array}{c}\text { Moongngram et al., } \\
2011^{4} \\
\text { (Inulin) }\end{array}$ & $\begin{array}{l}\text { Judprasong et al., } \\
2011^{5} \\
\text { (Inulin) }\end{array}$ & $\begin{array}{l}\text { Present study } \\
\text { (Inulin + FOS) }\end{array}$ \\
\hline Allium ampeloprasum & $3-10$ & 0.09 & - & - & 0.48 & $6.20 \pm 0.23$ \\
\hline Allium cepa & $2-6$ & 0.85 & - & $33.20 \pm 2.00$ & 0.44 & $8.60 \pm 0.88$ \\
\hline Allium sativum & $9-16$ & 0.39 & - & $41.72 \pm 1.17$ & 23.0 & $18.62 \pm 1.55$ \\
\hline Asparagus racemosus & - & - & $10-15$ & - & - & $11.83 \pm 0.87$ \\
\hline Beta vulgaris & - & 0.00 & - & - & - & $0.60 \pm 0.04$ \\
\hline Diascorea alata & - & - & - & $<0.01$ & - & $0.57 \pm 0.07$ \\
\hline I. batatas & - & - & - & $0.33 \pm 0.04$ & 0.48 & $\begin{array}{l}0.10 \pm 0.01^{\mathrm{a}} \\
0.24 \pm 0.07^{\mathrm{b}}\end{array}$ \\
\hline
\end{tabular}

1 - HPLC; 2 - HPLC with pulsed electrochemical detection (PED); 3 - colourimetric method using resorcinol and $\mathrm{HCl} ; 4$ - HPLC with refractive index detection (RID); 5 - gas chromatography (GC). a - I. batatas (red); b - I. batatas (yellow) 
higher than that was reported by Loo et al. (1995) (9$16 \mathrm{~g} / 100 \mathrm{~g} \mathrm{FW})$, while it was lesser than those reported by Moongngram et al. (2011) (41.72 $\pm 1.17 \mathrm{~g} / 100 \mathrm{~g} \mathrm{FW})$ and Judprasong et al. (2011) (23.0 g/100 g FW).

Table 4: Physico-chemical composition of selected food and herbal plants ( $\mathrm{g} / 100 \mathrm{~g}$ dry basis)

\begin{tabular}{|c|c|c|c|c|c|c|}
\hline Scientific name & Moisture & Ash & $\begin{array}{l}\text { Crude } \\
\text { protein }\end{array}$ & $\begin{array}{l}\text { Crude } \\
\text { fiber }\end{array}$ & $\begin{array}{c}\text { Crude } \\
\text { fat }\end{array}$ & $\begin{array}{c}\text { Total water } \\
\text { soluble sugars }\end{array}$ \\
\hline A. campanulatus & 84.48 & 2.33 & 2.83 & 9.95 & 1.00 & 54.80 \\
\hline C. indica L. (green) & 76.80 & 3.02 & 5.32 & 9.45 & 4.67 & 67.00 \\
\hline C. indica $\mathrm{L}$. (red) & 79.32 & 5.03 & 3.54 & 9.51 & 1.67 & 54.30 \\
\hline C. urens $\mathrm{L}$. & 13.66 & 2.30 & 4.89 & 1.34 & 2.34 & 63.20 \\
\hline D. alata $\mathrm{L}$. & 63.41 & 5.47 & 7.24 & 7.66 & 1.67 & 48.35 \\
\hline I. batatas (L.) Lam. (red) & 80.11 & 0.97 & 2.91 & 6.83 & 3.33 & 51.40 \\
\hline I. batatas (L.) Lam. (yellow) & 72.8 & 3.28 & 4.45 & 9.24 & 2.67 & 43.50 \\
\hline M. arundinacea $\mathrm{L}$. & 61.97 & 4.72 & 5.55 & 5.07 & 3.67 & 62.00 \\
\hline A.cepa $\mathrm{L}$. & 82.04 & 0.97 & 12.99 & 11.01 & 4.33 & 35.50 \\
\hline A. sativum $\mathrm{L}$. & 65.74 & 1.26 & 19.20 & 10.97 & 4.63 & 52.20 \\
\hline A. ampeloprasum $\mathrm{L}$. & 87.72 & 1.56 & 15.71 & 9.70 & 2.33 & 43.50 \\
\hline B. vulgaris $\mathrm{L}$. & 88.27 & 3.46 & 13.41 & 6.36 & 2.03 & 48.20 \\
\hline L. spinosa (L.) Thw. & 85.72 & 4.28 & 1.60 & 13.34 & 0.12 & 23.30 \\
\hline A. vera (L.) Burm.f. & 95.68 & 1.34 & 3.12 & 1.35 & 2.49 & 52.10 \\
\hline A. calcarata Roscoe. & 71.86 & 2.01 & 4.38 & 10.74 & 0.98 & 58.50 \\
\hline A. falcatus L. & 81.03 & 3.25 & 4.34 & 7.22 & 2.33 & 40.20 \\
\hline A. racemosus Willd. & 82.48 & 2.84 & 3.88 & 8.58 & 1.66 & 43.20 \\
\hline$V$. cinerea (L.) Less & 68.80 & 2.81 & 2.36 & 13.73 & 0.81 & 38.50 \\
\hline T. javanicum v. Soest & 79.19 & 3.60 & 5.23 & 12.90 & 0.93 & 38.90 \\
\hline S. oleraceus L. & 80.28 & 3.10 & 4.02 & 9.21 & 1.01 & 39.50 \\
\hline
\end{tabular}

Mean values obtained from three independent measurements

The inulin level in Allium ampeloprasum (leeks) in this study $(6.2 \pm 0.23 \mathrm{~g} / 100 \mathrm{~g} \mathrm{FW})$ was in agreement with that reported by Loo et al. (1995) (3-10 g/100 g FW), while Allium cepa showed a higher inulin content $(8.6 \pm$ $0.88 \mathrm{~g} / 100 \mathrm{~g} \mathrm{FW})$ than that was reported by Loo et al. in 1995 (2- $6 \mathrm{~g} / 100 \mathrm{~g} \mathrm{FW})$.

The inulin level in Asparagus racemosus found in this study $(11.83 \pm 0.87 \mathrm{~g} / 100 \mathrm{~g})$ was in accordance with that reported as $10-15 \mathrm{~g} / 100 \mathrm{~g} \mathrm{FW}$ by Gupta and Kaur (1997).

The differences in the reported values may be due to the analytical method used, the variation in climatic conditions, soil conditions, maturity levels and varieties of the particular plant (Carvalho et al., 1998; Kociss et al., 2007; Vandoorne et al., 2012).

Loo et al. (1995) reported Taraxacum officinale (Dandelion) as an inulin rich source $(12-15 \mathrm{~g} / 100 \mathrm{~g}$
FW). However, Taraxacum javanicum found in Sri Lanka showed only $5.77 \pm 1.53 \mathrm{~g} / 100 \mathrm{~g} \mathrm{FW}$ inulin.

According to the present study Maranta arundinacea (Arrowroot), which is commonly used in Ayurveda and Sri Lankan traditional medicine for correcting bowel complaints and diarrhea (Jayasinghe et al., 1979; Jayaweera, 1982) ) contained only $0.04 \pm 0.01 \mathrm{~g} / 100 \mathrm{~g} \mathrm{FW}$ of inulin, indicating that most probably its medicinal effect is delivered through another mechanism.

\section{Some other constituents of plant samples}

The results of the physico-chemical analysis are presented in Table 4. The moisture content was lowest in Caryota urens pith flour $(13.66 \mathrm{~g} / 100 \mathrm{~g})$, followed by Maranta arundinacea $(61.97 \mathrm{~g} / 100 \mathrm{~g})$ and Diascorea alata $(63.41$ $\mathrm{g} / 100 \mathrm{~g})$. As expected, the moisture content was highest in Aloe vera leaf gel $(95.68 \mathrm{~g} / 100 \mathrm{~g})$. 
Allium species showed the highest crude protein values among the analyzed plants, namely Allium sativum $(19.20 \mathrm{~g} / 100 \mathrm{~g})$, Allium ampeloprasum $(15.71 \mathrm{~g} / 100 \mathrm{~g})$ and Allium cepa $(12.99 \mathrm{~g} / 100 \mathrm{~g})$ on dry weight basis.

The crude fiber content on dry matter basis was the highest in Vernonia cinerea $(13.73 \mathrm{~g} / 100 \mathrm{~g})$ followed by Lasia spinosa (13.34 g/100 g) and Taraxacum javanicum (12.9 g/100 g). Canna indica (green), Allium sativum and Allium cepa showed comparatively high crude fat contents among the analyzed plants; 4.67, 4.63 and 4.33 $\mathrm{g} / 100 \mathrm{~g}$, respectively on dry matter basis.

As shown in Table 4, high water soluble sugar levels were found in Canna indica green $(67.00 \mathrm{~g} / 100 \mathrm{~g})$, Caryota urens $(63.20 \mathrm{~g} / 100 \mathrm{~g})$, Maranta arundinacea $(62.0 \mathrm{~g} / 100 \mathrm{~g})$ and Alpinia calcarata $(58.50 \mathrm{~g} / 100 \mathrm{~g})$ on dry weight basis.

\section{CONCLUSION}

Among the twenty plants analyzed, seven plants showed considerably high amounts (>4 g/100 g FW) of fructan. The fructan contents in the seven plants in descending order were Allium sativum $>$ Asparagus falcatus $>$ Asparagus racemosus $>$ Allium cepa $>$ Allium ampeloprasum $>$ Taraxacum javanicum $>$ Vernonia cinerea $(18.62 \pm 1.55,17.74 \pm 1.29,11.83 \pm 0.87,8.60 \pm$ $0.88,6.20 \pm 0.23,5.77 \pm 1.53,4.55 \pm 0.93 \mathrm{~g} / 100 \mathrm{~g} \mathrm{FW}$, respectively). These plants can be considered as locally available food sources with inulin-type fructans.

According to the present study, the inulin content in Asparagus falcatus $(17.74 \pm 1.29 \mathrm{~g} / 100 \mathrm{~g} \mathrm{FW})$ was comparable to that of chicory (Cichorium intybus), which was reported as $15.2-20.5 \mathrm{~g} / 100 \mathrm{~g} \mathrm{FW}$ (Loo et al., 1995). Thus Asparagus falcatus could be a potential source for the commercial production of inulin.

\section{Acknowledgement}

The authors wish to thank Prof. Piyal Marasinghe, Associate Professor, Department of Ayurveda, Sri Lanka for his valuable support in selecting plants for screening. The HETC project, Sri Lanka is acknowledged for funding this research.

\section{REFERENCES}

1. Association of Official Agricultural Chemists (AOAC) (2005). Official Methods of Analysis. AOAC International, Maryland, USA.
2. Campbell J.M., Bauer L.L., Fahey G.C., Hogarth A.J.C.L., Wolf B.W. \& Hunter D.E. (1997). Selected fructooligosaccharide (1-Ketose, Nystose and 1- $\beta$ Fructofuranosylsystose) composition of foods and feeds. Journal of Agricultural Food Chemistry 45: 3076 - 3082. DOI: http://dx.doi.org/10.1021/jf970087g

3. Carvalho M.A.M.D., Pinto M.M. \& Figueiredo-Ribeiro R.D.C.L. (1998). Inulin production by Vernonia herbacea as influenced by mineral fertilization and time of harvest. Revista Brasileira de Botanica 21(3): 275 - 280.

4. Dubois M., Gilles K.A., Hamilton J.K., Rebers P.A. \& Smith F. (1956). Colourimetric method for determination of sugar and related substances. Analytical Chemistry 28(3): $350-356$.

DOI: http://dx.doi.org/10.1021/ac60111a017

5. Gupta A.K. \& Kaur N. (1997). Fructan storing plantsA potential source of high fructose syrups. Journal of Scientific and Industrial Research 56: $447-452$.

6. Hahn-Deinstrop E. (ed). (2007). Applied Thin-Layer Chromatography; Best Practice and Avoidance of Mistakes. Wiley-VCH, Weinheim, Germany.

7. Jayasinghe D.M., Kumarasinghe A., Weerasinghe L. \& RamanayakeH.A.L.(eds.)(1979).AyurvedaPharmacopoeia. Department of Ayurveda, Nawinna, Maharagama.

8. Jayasinghe D.M., Kumarasinghe A., Weerasinghe L. \& Ramanayake H.A.L. (eds.) (1985). Ayurveda Pharmacopoeia. Department of Ayurveda, Nawinna, Maharagama.

9. Jayaweera D.M.A. (1980). Medicinal Plants (Indigenous and Exotic) used in Ceylon. part II: Cactaceae-Fagaceae. National Science Council of Sri Lanka, 47/5, Maitland Place, Colombo 07.

10. Jayaweera D.M.A. (1981b). Medicinal Plants (Indigenous and Exotic) used in Ceylon, part I: AcanthaceaeBurseraceae. National Science Council of Sri Lanka, 47/5, Maitland Place, Colombo 07.

11. Jayaweera D.M.A. (1981a). Medicinal Plants (Indigenous and Exotic) used in Ceylon, part III: FlacourtiaceaeLythraceae. National Science Council of Sri Lanka, 47/5, Maitland Place, Colombo 07.

12. Jayaweera D.M.A. (1982). Medicinal Plants (Indigenous and Exotic) used in Sri Lanka, part IV: MagnoliaceaeRubiaceae. National Science Council of Sri Lanka, 47/5, Maitland Place, Colombo 07.

13. Judprasong K., Tanjor S., Puwastien P. \& Sungpuag P. (2011). Investigation of Thai plants for potential sources of inulin-type fructans. Journal of Food Composition and Analysis 24: 642 - 649 .

DOI: http://dx.doi.org/10.1016/j.jfca.2010.12.001

14. Kociss L., Liebhard P. \& Praznik W. (2007). Effect of seasonal changes on content and profile of soluble carbohydrates in tubers of different varieties of Jerusalam Artichoke (Helianthus tuberosus L.). Journal of Agricultural and Food Chemistry 55: 9401 - 9408. DOI: http://dx.doi.org/10.1021/jf0717485

15. Loo J.V., Coussement P., Leenheer L.D., Hoebregs H. \& Smits G. (1995). On the presence of inulin and oligofructose as natural ingredients in the western diet. Critical Reviews 
in Food Science and Nutrition 35(6): 525 - 552.

DOI: http://dx.doi.org/10.1080/10408399509527714

16. McCleary B.V., Murphy A. \& Mugford D.C. (2000). Measurement of total fructan in foods by enzymatic/ spectrophotometric method: collaborative study. Journal of AOAC International 83(2): 356 - 364.

17. Megazyme (2012). Megazyme Fructan Assay Procedure for the Measurement of Fructooligosaccharides and Fructan Polysaccharide. Megazyme International Ireland, Wicklow, Ireland.

18. Moongngarm A., Trachoo N. \& Sirigungwan N. (2011). Low molecular weight carbohydrates, prebiotic content and prebiotic activity of selected food plants in Thailand. Advance Journal of Food Science and Technology 3(4): $269-274$.

19. Niness K.R. (1999). Inulin and oligofructose: what are they? The Journal of Nutrition 129: 1402S - 1406S.

20. Reiffova K. \& Nemcova R. (2006). Thin layer chromatography analysis of fructooligosaccharides in biological samples. Journal of Chromatography A 1110: $214-221$

DOI: http://dx.doi.org/10.1016/j.chroma.2006.01.039

21. Roberfroid M. (2005). Inulin-type Fructans. Functional
Food Ingredients. CRC Press, London, UK.

22. Roberfroid M.B. (2007a). Prebiotics: the concept revisited. The Journal of Nutrition 137: 830S - 837S.

23. Roberfroid M.B. (2007b). Inulin-type fructans: functional food ingredients. Journal of Nutrition 137(11): 2493S 2502S.

24. Sako T. \& Tanaka R. (2002). Prebiotics. Encyclopedia of Dairy Sciences, pp. 2268 - 2275. Academic Press, London, UK.

25. Senaratna L.K. (2001). A Check List of the Flowering Plants of Sri Lanka. National Science Foundation of Sri Lanka, 47/5, Maitland Place, Colombo 07.

26. Singh R.S. \& Singh R.P. (2010). Production of fructooligosaccharides from inulin by endoinulinase and their prebiotic potential. Food Technology and Biotechnology 48(4): 435 - 450.

27. Vandoorne B., Mathieu A.S., Ende W.V.D., Vergauwen R., Perilleux C., Javaux M. \& Lutts S. (2012). Water stress drastically reduces root growth and inulin yield in Cichorium intybus (var. sativum) independently of photosynthesis. Journal of Experimental Botany 63(12): $4359-4373$.

DOI: http://dx.doi.org/10.1093/jxb/ers095 